Article

\title{
Optimal Operation of Floodwater Resources Utilization of Lakes in South-to-North Water Transfer Eastern Route Project
}

\author{
Zitong Yang ${ }^{1}$, Xianfeng Huang ${ }^{1, *}$, Jiao Liu ${ }^{2}$ and Guohua Fang ${ }^{1}$ \\ 1 College of Water Conservancy and Hydropower Engineering, Hohai University, Nanjing 210098, China; \\ ztyang@hhu.edu.cn (Z.Y.); ghfang@hhu.edu.cn (G.F.) \\ 2 Energy Engineering Group Guangdong Electric Power Design Institute Co., Ltd., Guangzhou 510663, China; \\ jojoaliu@163.com \\ * Correspondence: xfhuang@hhu.edu.cn; Tel.: +86-159-96267968; Fax: +86-025-83786511
}

Citation: Yang, Z.; Huang, X.; Liu, J.; Fang, G. Optimal Operation of Floodwater Resources Utilization of Lakes in South-to-North Water Transfer Eastern Route Project. Sustainability 2021, 13, 4857. https:/ / doi.org/10.3390/su13094857

Academic Editor: Anastasios Michailidis

Received: 24 March 2021

Accepted: 23 April 2021

Published: 26 April 2021

Publisher's Note: MDPI stays neutral with regard to jurisdictional claims in published maps and institutional affiliations.

Copyright: (c) 2021 by the authors. Licensee MDPI, Basel, Switzerland. This article is an open access article distributed under the terms and conditions of the Creative Commons Attribution (CC BY) license (https:/ / creativecommons.org/licenses/by/ $4.0 /)$.

\begin{abstract}
In order to meet the demand of emergency water supply in the northern region without affecting normal water transfer, considering the use of the existing South-to-North Water Transfer eastern route project to explore the potential of floodwater resource utilization in the flood season of Hongze Lake and Luoma Lake in Jiangsu Province, this paper carried out relevant optimal operating research. First, the hydraulic linkages between the lakes were generalized, then the water resources allocation mode and the scale of existing projects were clarified. After that, the actual available amount of flood resources in the lakes was evaluated. The average annual available floodwater resources in 2003-2017 was 1.49 billion $\mathrm{m}^{3}$, and the maximum available capacity was 30.84 billion $\mathrm{m}^{3}$. Then, using the floodwater resource utilization method of multi period flood limited water levels, the research period was divided into the main flood season (15 July to 15 August) and the later flood season (16 August to 10 September, 11 September to 30 September) by the Systematic Clustering Analysis method. After the flood control calculation, the limited water level of Hongze Lake in the later flood season can be raised from $12.5 \mathrm{~m}$ to $13.0 \mathrm{~m}$, and the capacity of reservoir storage can increase to 696 million $\mathrm{m}^{3}$. The limited water level of Luoma Lake can be raised from $22.5 \mathrm{~m}$ to $23.0 \mathrm{~m}$ (16 August to 10 September), $23.5 \mathrm{~m}$ (11 September to 30 September), and the capacity of reservoir storage can increase from 150 to 300 million $\mathrm{m}^{3}$. Finally, establishing the floodwater resource optimization model of the lake group with the goals of maximizing the floodwater transfer amount and minimizing the flood control risk rate, the optimal water allocation scheme is obtained through the optimization algorithm.
\end{abstract}

Keywords: floodwater resource utilization; utilization pattern; stage water level; optimized scheduling

\section{Introduction}

The spatial and temporal distribution of water resources in China are very different, and decrease from southeast to northwest. The annual precipitation in eastern China is relatively large; $70 \%$ of the precipitation is concentrated in the flood season from June to September, which often leads to frequent flood disasters. This feature has become an important constraint factor for China's economic and social development. In order to alleviate the shortage of water resources in North China, a series of inter basin water transfer projects should be put into operation. The utilization of unconventional water resources, such as rainwater and flood resources, has gradually come into people's vision, and the concern of the flood management concept has changed from defense and response to rational utilization and allocation. The method of flood resource utilization is to give consideration to the point (reservoir, dam), line (river, channel, dike) and surface (flood storage and detention area, field and surface), paying equal attention to engineering measures, non-engineering measures and management measures, and organically combine storage, discharge, detention, diversion and compensation [1]. Deng, PX [2] put forward the evaluation method of rain-flood utilization availability at the distributed watershed 
scale and applied it to water resources management in the Hanjiang River Basin. Liu, YQ [3] proposed a new algorithm, named the multi-objective cultured evolutionary algorithm based on decomposition (MOCEA/D), and applied it to a case study of HFORs optimization for the Three Gorges Project (TGP). Takeuchi, K [4] shows the process by which the ever-increasing flood damage potential and the recent increase in flood damages necessitated the official move in flood control management from rivers to basins. Kumar, DN [5] adopted Folded Dynamic Programming (FDP) for developing optimal reservoir operation policies for flood control and applied it to a case study of the Hirakud Reservoir in the Mahanadi basin, India. On the premise of ensuring the safety of flood control and not damaging the ecological health of the river, it is necessary to transform part of the flood into conventional water resources, so as to improve the carrying capacity of water resources in the basin. The basins in northern China are often driven by the need to tap the potential of water resources. In recent years, typical analysis and exploration have been carried out on the implementation of flood forecasting and regulation, and the adjustment of the flood limit water level of some reservoirs, and good results have been achieved [6].

In recent years, scholars from all over the world have carried out a series of studies on the utilization of flood resources. Based on the historical data of the relevant parameters of water resources management, Pal, SK [7] concluded that the flexible flood control policy will help to bring more benefits. G Zhai [8] establishes a framework of a multi-risk context and examines how other risks affect flood risk acceptability by using a survey conducted in the Toki-Shonai River region of Japan. I Maqsood [9] introduces a hybrid optimization approach for flood management under multiple uncertainties and its dual formation is developed by integrating the concepts of mixed-integer and interval-parameter programming techniques into a general framework of two-stage stochastic programming. Sheehan, J [10] highlight how crucial private stakeholders are to the effectiveness of any instrument for flood risk and hence, their direct impact on the effectiveness of flood management. Mobley, W [11] proposed using random forest classification to predict flood probability and using the national flood insurance program (NFIP) to predict flood disaster. At present, the utilization of flood resources mainly focuses on improving the limited water level of flood control during flood season by using the existing water conservancy projects combined with the rainfall runoff forecast and other non-engineering measures [12], and realizing the utilization of flood resources through the risk and benefit management of the reservoir [13].

The South-to-North Water Transfer Project (SNWT Project) is a super large infrastructure to alleviate the water shortage in northern China [14]. Since the completion of the Jiangsu section of phase I of the east line of the SNWT Project at the end of 2013, four water transfer operations have been carried out, but the net increase in water supply has not reached the expected planning value. At present, there is still a period of time before the start of the phase II project. Using phase I of the project to expand the emergency water supply is needed to alleviate the shortage of water resources in northern China. Due to the large amount of available flood resources in Hongze Lake and Luoma Lake, it is the key to adopt the optimal scheduling scheme to reduce the flood control risk on the basis of appropriately increasing the flood limit water level. This paper intends to evaluate the flood resources' utilization potential of lakes in the East Route of the SNWT Project, analyze the reasonable flood resources utilization mode, construct the optimal operation model of flood resources of lakes in the SNWT Project with the goal of maximizing the flood diversion amount and minimizing flood control risk, and use the improved particle swarm optimization algorithm to solve the problem. Finally, the optimal scheme is determined by a comprehensive benefit calculation.

\section{Materials and Methods}

\subsection{General Situation of Jiangsu Section of Phase I of East Line of SNWT Project}

The SNWT Project is an important strategic measure to solve the serious shortage of water resources in the northern regions of China, and it is also a super large infrastructure 
related to the sustainable development of China's economy and society. Since the Jiangsu section of phase I of the east line of the SNWT Project was successfully opened in 2013, according to the dispatching requirements of relevant national and provincial departments, 10 times water transfer tasks to Shandong have been completed, with a total of 111,700 operation hours, 11.166 billion $\mathrm{m}^{3}$ of pumping water, 1.698 billion $\mathrm{m}^{3}$ of pumping water, and 1.994 billion $\mathrm{m}^{3}$ of water out of the province. At the same time, the project has participated in flood control, flood drainage, drought resistance and other related work in the province many times, with 27,900 operation hours and 2.941 billion $\mathrm{m}^{3}$ of pumping water. However, the project has some negative hydrological and environmental impacts. With the gradual increase in water transfer in the future, the impact on the water level of the Yangtze River below the water transfer mouth, the siltation of the river channel and the position of the mouth bar will be intensified. At the same time, the water quality of the project is easily affected by the pollution discharge of the cities along the line. With the establishment of the integrated pollution control system along the line, the total discharge of main pollutants has been reduced by more than $80 \%$, the total amount of water into the river has basically reached the target control requirements, and the water quality and ecological environment along the line have been continuously improved. The sketch map of the Jiangsu section of phase I of the east line of the SNWT Project is shown in Figure 1 [15].

Jiangsu section of phase I of east line of South-to-North water transfer project Sketch Map

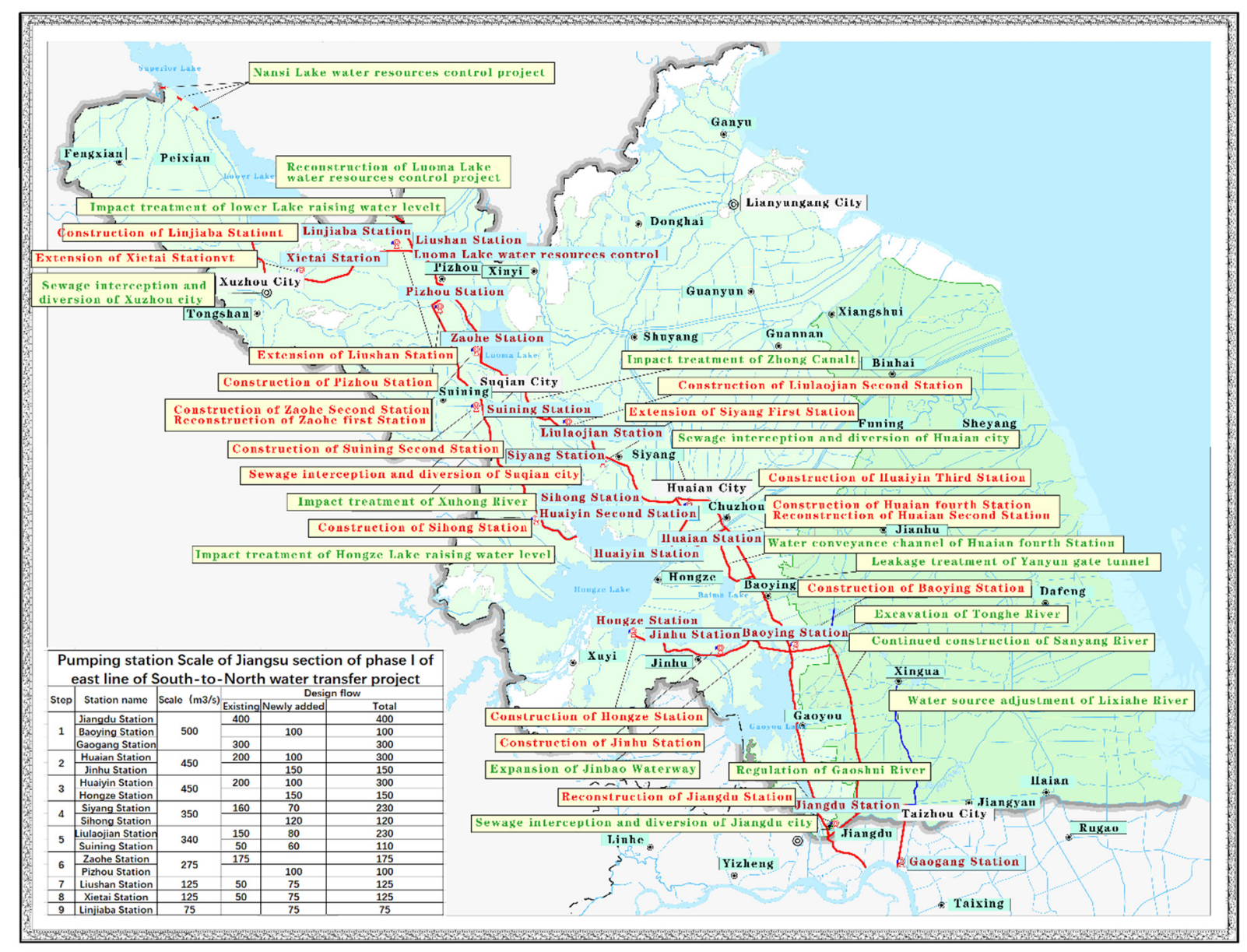

Figure 1. Jiangsu section of phase I of east line of SNWT project sketch map. 


\subsection{System Generalization and Engineering Overview}

\subsubsection{Generalization of Lake Group System}

The East Route of the SNWT Project starts from Jiangdu station, connecting Hongze Lake, Luoma Lake, Nansi Lake and Dongping Lake, undertakes the water supply task of $180,000 \mathrm{~km}^{2}$ in the east of Huanghuaihai Plain and the Jiaodong area, and connects with the Xintongyang canal, North Jiangsu irrigation canal, Huaishu River, Xinyi River and other key rivers along the way. The system is huge and complex, and it is difficult to consider all factors. On the basis of fully considering the working characteristics of pump gate station and the hydraulic connection between rivers and lakes, the system is generalized with lakes as the water allocation center, focusing on the allocation mode of flood resources among lakes, as shown in Figure 2 [16].

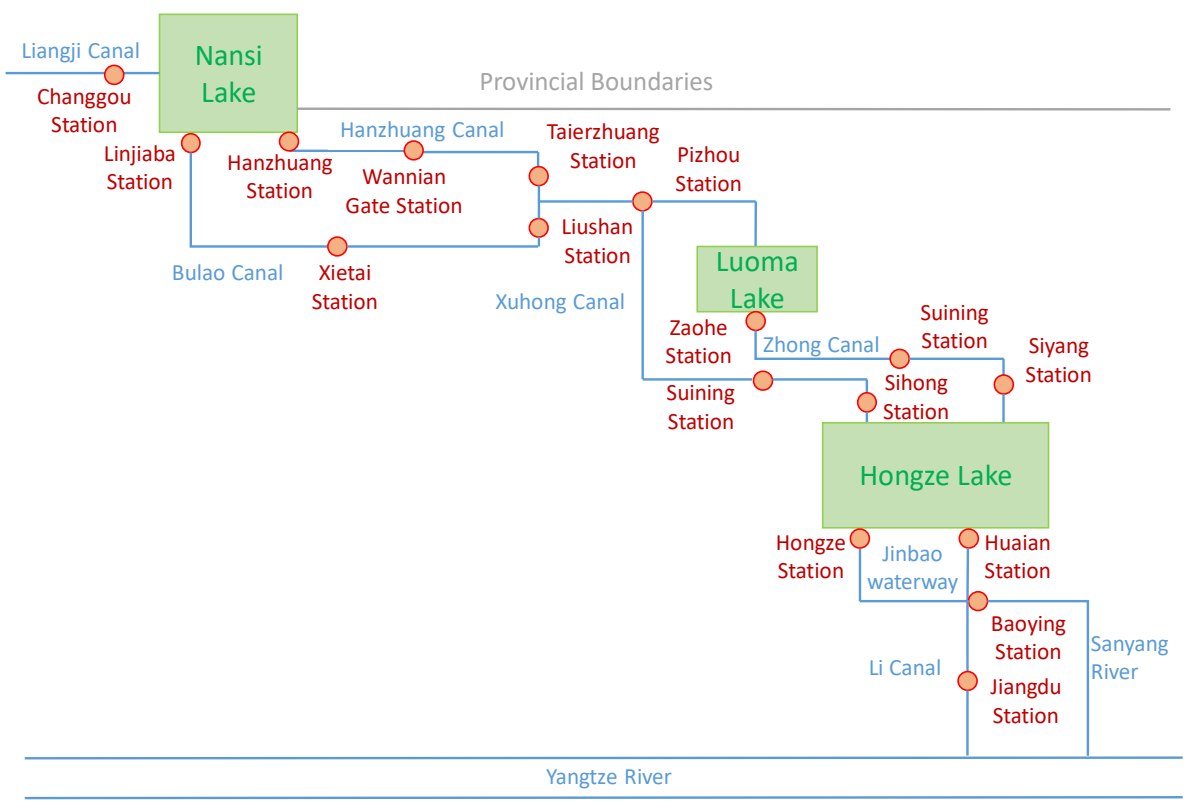

Figure 2. Lake group water transfer system generalization map.

As shown in Figure 2, taking Hongze Lake, Luoma Lake, Nansi Lake and Dongping Lake as water allocation centers, the whole system is divided into the Jiangsu section and Shandong section, with emphasis on the water transfer route between the lakes and the pumping stations along the line. This paper mainly studies the utilization of flood resources in the Jiangsu section of the eastern route during flood season. In the generalization, it ignores the water receiving area in the normal route of the SNWT Project, as well as the pump gate station and water delivery route which are not in the emergency water supply line. This paper does not consider the water storage capacity of the river and the water distribution between the two lines.

\subsubsection{General Situation of Pumping Station Project System}

The Jiangsu section of the East Route of the SNWT Project is equipped with 9-level pumping stations, which have low lift (mostly $2-6 \mathrm{~m}$ ), large flow (the single unit flow is generally $15-40 \mathrm{~m}^{3} / \mathrm{s}$ ), and long operation time. Some of the pumping stations also have the task of drainage. It is very important to make clear the design scale and operation conditions of all levels of pumping stations connecting with lakes for the utilization of flood resources [17]. The general situation of the Hongzehu pumping station project in the Jiangsu section of the first phase of the East Route is shown in Table 1 [15]. 
Table 1. Basic situation of the first phase pump station project of the East Route.

\begin{tabular}{|c|c|c|c|c|c|}
\hline Section & Level & $\begin{array}{l}\text { Name of Pumping } \\
\text { Station }\end{array}$ & $\begin{array}{c}\text { Design } \\
\text { Scale/(m³ } / \mathbf{s})\end{array}$ & Design Head/(m) & $\begin{array}{c}\text { Number of } \\
\text { Installed Units }\end{array}$ \\
\hline & 4 & Siyang Station & 230 & 6.3 & 6 \\
\hline & 4 & Sihong Station & 120 & 3.7 & 5 \\
\hline Hongze Lake & 5 & Liulaojian Station & 230 & 3.7 & 4 \\
\hline \multirow[t]{5}{*}{ Luoma Lake } & 5 & Suining Station & 110 & 9.2 & 3 \\
\hline & 6 & Zaohe Station & 175 & 4.65 & 2 \\
\hline & 6 & Pizhou Station & 100 & 3.2 & 4 \\
\hline & 7 & Liushan Station & 125 & 5.73 & 5 \\
\hline & 7 & Taierzhuang Station & 125 & 4.53 & 6 \\
\hline Luoma Lake & 8 & Xietai Station & 125 & 5.84 & 5 \\
\hline \multirow{3}{*}{ Nansi Lower Lake } & 8 & Wannian Gate Station & 125 & 5.49 & 5 \\
\hline & 9 & Linjiaba Station & 75 & 2.4 & 4 \\
\hline & 9 & Hanzhuang Station & 125 & 4.15 & 5 \\
\hline
\end{tabular}

It is expected that the utilization of abandoned water during flood season of lakes will not affect the normal water transfer of the SNWT Project, and the main operation period of each year from October to May of the following year will be avoided. The operation of pumping stations during flood season can increase the operation time of pumping stations along the line in a year and reduce idle operation, but correspondingly, a part of water and electricity consumption will be increased, which will affect the drainage work and maintenance of pump stations during flood season. Meanwhile, the uncertainty of flood may also lead to unstable working time and pumping volume of pumping stations. The pump station is the core of the SNWT Project [18]. The efficiency of the pump station directly affects the water supply of the East Route of the SNWT Project. The increase in the water supply time of the pump station will also cause an increase in the operation cost of the pump stations. It is also necessary to maintain, replace the new water pump and select a reasonable motor in a timely manner. Therefore, standardizing the management of the pumping station, improving its management level, strengthening technical training and heightening the quality of management staff are important measures to improve the operation efficiency of the pumping station, reduce the operation cost and ensure the time of water replenishment [19].

\subsection{Utilization Mode and Potential Evaluation of Flood Resources}

\subsubsection{Estimation of Available Flood Resources}

In order to realize the optimal operation of flood resources, the available amount of flood resources should be estimated. According to the data of the lake in and out of the lake in a certain period, the annual flood season is determined, and the amount of water discharged during this period is temporarily called abandoned water. However, considering the limited storage capacity of lakes and the limitations of corresponding water transfer engineering measures, it is difficult to fully utilize the floodwater resource during flood season. When calculating the available amount of flood resources of lakes, the scale of corresponding pumping stations, the requirements of opening and closing, the water carrying capacity of water conveyance channels and the ecological water shortage in Jiangsu Province should be considered. Taking the basin as a water storage system, $x$ is the maximum flood resources that can be regulated, stored and utilized during the flood season when the flood control safety is guaranteed.

The available amount of floodwater resources in the basin with defined period $t$ corresponding to flood regulation and utilization capacity $x$ can be described as follows:

$$
Q_{a}^{x}(t)=Q_{1}(t)-g\left(Q_{4}(t), Q_{u}^{x}(t)\right)
$$

$Q_{1}(t)$ is the inflow flood of period $t, Q_{4}(t)$ is to ensure that the water receiving area and ecological water shortage are not allowed to be used; $Q_{u}^{x}(t)$ is the unavailable floodwater 
resources limited by the system regulation and utilization capacity $x ; g\left(Q_{4}(t), Q_{\mathcal{u}}^{x}(t)\right)$ is the "un-utilizable" amount of floodwater resources corresponding to $x$.

\subsubsection{Selection of Floodwater Resources Utilization Mode}

At present, most of the reservoirs in China operate according to the single limited water level during the whole flood season to prevent the occurrence of small probability flood events. However, precipitation during the flood season is not uniform, and the adoption of fixed flood limit water levels is seriously inconsistent with the fact that the time distribution during the flood season is uneven, which often leads to the embarrassing situation of having more abandoned water during the flood season and the difficulty of filling up after the flood season, and the precious water resources are not effectively utilized [20]. Therefore, under the premise of ensuring the safety of flood control, it is considered an effective way to utilize flood resources to optimize the limited water level of reservoirs during flood season. Considering the limited level of rainfall and flood forecast in Hongze Lake and Luoma Lake, the flood resource utilization mode of using flood limited water levels by stages is adopted to control and utilize flood resources to the maximum extent, so as to supply emergency water shortage in North China.

The application of flood control water level by stages is divided into flood season division, design flood calculation by stages and flood limit water level calculation by stages [21]. Based on the data of the daily inflow of lakes, the maximum ten-day inflow, the maximum 3-day runoff and the maximum 7-day inflow during flood season are calculated. Establishing the multi-dimensional time series matrix, the research period of the flood season is divided into the main flood season and the later flood season. Among them, the period of the main flood season is the period of high flood occurrence in the basin with abundant incoming water, which mainly meets the requirements of flood control; in the later flood season, the flood control pressure will be reduced to a certain extent, so it is considered to gradually raise the flood limit water level to ensure that the reservoir can be full at the end of the flood season. In order to reduce the risk of flood control, the rising range of water level in the first half of the later flood season should be controlled.

\subsection{Optimal Operation of Floodwater Resources Utilization of Lakes}

\subsubsection{Establishment of Floodwater Resource Utilization Model for Lakes}

(1) Objective Function:

The purpose of floodwater resource utilization of the East Route of the SNWT project is to realize the maximum benefit of flood resources through the existing water transfer scale under the condition that the flood control safety during flood season and the normal operation of the project are not affected. Therefore, the objective function of the optimal operation model is established by considering the two objectives of maximum floodwater utilization amount and minimum comprehensive risk value of flood control.

(I) The maximum amount of floodwater utilization:

The maximum amount of floodwater regulation is to transfer floodwater resources out of Jiangsu Province as much as possible:

$$
O B J 1=\max \sum_{t} Q S(j, t)
$$

$t$ is the sequence number of the period; $j$ is the number of pump station, $Q S(j, t)$ is the pumping capacity of pump station $j$ of Liangji Canal in period $t, 10^{8} \times \mathrm{m}^{3}$.

(II) The minimum comprehensive risk value of flood control:

According to the lake, river channel and pumping station of the water transfer route, the main risk indicators of floodwater resources utilization in the East Route are identified through the engineering sketch map. The risk of water storage project mainly includes the risk of over storage of Hongze Lake and Luoma Lake. The risk of the water conveyance project includes the risk of super capacity of the Zhong Canal, Xuhong River, Bulao River and Hanzhuang Canal. The risk of the water lifting project includes the risk of exceeding 
the engineering design water level of Siyang station, Sihong station, Liulaojian station, Suining station, Zaohe station, Pizhou station and Liushan pumping station. Based on the full analysis of hydrological data and engineering parameters, the risk rate is calculated in combination with the water transfer of each period. The risk evaluation value is obtained by estimating the risk loss and considering the severity of the consequences. The product of the risk rate and risk evaluation value is taken as the risk evaluation value of each index. Finally, the comprehensive risk of flood control is obtained by the weighted sum of the risk value of each index value [22-24].

$$
O B J_{2}=\min \left[w_{1} \sum_{i} R X(i, t)+w_{2} \sum_{j} R Q(j, t)+w_{3} \sum_{k} R R(k, t)\right]
$$

$i$ is the number of lakes (1-Hongze Lake, 2 -Luoma Lake), $j$ is the number of pump station (1-Siyang Station, 2-Sihong Station, 3-Liulaojian Station, 4-Suining Station, 5Zaohe Station, 6-Pizhou Station, 7-Liushan Station), $k$ is the number of Canal (1-Zhong Canal, 2-Xuhong Canal, 3-Bulao Canal, 4-Hanzhuang Canal), $R X(i, t)$ is the risk of water storage project in period $t, R Q(j, t)$ is the risk of water lifting project in period $t, R R(k, t)$ is the risk of water conveyance project in period $t$, and $w 1, w 2, w 3$ are the corresponding combination weights of the three risk indicators.

(2) Constraint conditions:

(I) Water balance constraints in lakes:

$$
V(i, t+1)=V(i, t)+Q(i, t)+D I(i, t)+P C(i+1, t)-D O(i, t)-P R(i, t)
$$

$Q(i, t)$ is the inflow runoff of $i$ lake in $t$ period, $10^{8} \times \mathrm{m}^{3} . D O(i, t), D I(i, t)$ are the inflow and outflow of $i$ lake in $t$ period, $10^{8} \times \mathrm{m}^{3}$. PC $(i, t)$ is the water discharged into $i$ lake in $t$ period, $10^{8} \times \mathrm{m}^{3}$. $P R(i, t)$ is the water discharged from $i$ lake in $t$ period, $10^{8} \times \mathrm{m}^{3}$.

(II) Working capacity constraints of pumping stations:

$$
\left\{\begin{aligned}
0 \leq D O(i, t) & \leq D O_{\max }(i, t) \\
0 \leq D I(i, t) & \leq D I_{\max }(i, t)
\end{aligned}\right.
$$

DOmax, DImax are the pumping capacity of lakes and corresponding pumping station, $10^{8} \times \mathrm{m}^{3}$.

(III) Capacity constraints of reservoir storage:

$$
V_{\min }^{*}(i, t) \leq V(i, t) \leq V_{\max }^{*}(i, t)
$$

$V \min , V \max$ are the minimum and maximum water storage capacity of the lake in each period, $10^{8} \times \mathrm{m}^{3}$.

(IV) Maximum discharge capacity constraints of control gate station:

$$
0 \leq P R(i, t) \leq P R_{\max }(i, t)
$$

$\operatorname{PRmax}(i, t)$ is the maximum discharge capacity of the corresponding control gate station, $10^{8} \times \mathrm{m}^{3}$.

(V) Constraints of control water level:

$$
Z_{\min }(i, t) \leq Z(i, t) \leq Z_{\max }(i, t)
$$

$Z \min (i, t), Z \max (i, t)$ are the lowest and highest control water levels of $i$ lake in $t$ period. The control water level is determined by the stage limited water levels.

(VI) Other constraints include constraints of canal water carrying capacity, nonnegative constraints, etc. 


\subsubsection{Solution Algorithm}

In this paper, an improved multi-objective particle swarm optimization (MOPSO) algorithm is used to solve the optimal operation of floodwater resources utilization of lakes. Aiming at the problems of local convergence and uneven distribution of the Pareto front in the particle swarm optimization algorithm [25], the following improvements are made [26]:

(1) The adaptive inertia weight strategy can change the single of the PSO algorithm in the actual search process, so that it can adapt to the complex real environment. The optimal fitness change rate $k$ is defined as follows:

$$
k=\frac{|f(t)-f(t-5)|}{|f(t-5)|}
$$

where, $f(t)$ is the optimal fitness value of the $t$-th generation of the population; $f(t-5)$ is the optimal fitness value of the $(t-5)$-th generation of the population; $k$ is the relative change rate of the optimal fitness value of the population in the last 5 generations. The value of inertia weight $w$ is adjusted adaptively with the size of $k$, as shown in Formula (10):

$$
w=\left\{\begin{array}{l}
\alpha_{1}+r / 2.0, k \geq 0.05 \\
\alpha_{2}+r / 2.0, k<0.05
\end{array}\right.
$$

where, $r$ is a random number uniformly distributed between $[0,1]$. When $k \geq 0.05$, the optimal fitness value of the population changes greatly in the evolution process, and the population is in the exploration stage. At this time, the larger inertia weight is conducive to the convergence of the algorithm, and its mathematical expectation is $E(w)=\alpha_{1}+0.25$. When $k<0.05$, the change of the optimal fitness value of the population in the evolution process is small, and the population is in the development stage. At this time, taking a small value of inertia weight is conducive to obtaining an accurate solution, which is $E(w)=\alpha_{2}+0.25 . \alpha_{1}>\alpha_{2}$, generally $\alpha_{1}=0.6, \alpha_{2}=0.2$.

(2) The average particle distance is used to describe the diversity of the population to avoid the premature convergence problem caused by the lack of population diversity in the actual search process of the PSO algorithm. Let $L$ be the maximum diagonal length of the search space, $S$ be the size of the population, $n$ be the dimension of the solution space, $x_{i d}^{t}$ be the $i$-th coordinate value of the $d$-th particle, and $\bar{p}_{d}$ be the mean value of the $d$-th coordinate value of all particles. Then the average grain distance $D(t)$ of the population in the $i$-th iteration is defined as follows:

$$
D(t)=\frac{1}{S \cdot L} \sum_{i=1}^{S} \sqrt{\sum_{d=1}^{n}\left(x_{i d}^{t}-\bar{P}_{d}\right)^{2}}
$$

The average particle distance describes the dispersion degree of distribution among particles in the population. The smaller the $D(t)$, the more concentrated the population is.

Through the improved particle swarm optimization algorithm, the uniform non inferior solution set can be obtained. Finally, the energy analysis method and the ecological environment water use benefit sharing coefficient method are used to calculate the benefit and cost of flood resources utilization of each water transfer scheme. Combined with the possible loss of corresponding risk degrees and treatment measures, the comprehensive benefit of each scheme is calculated, so as to determine a more reasonable flood resource utilization scheme.

In order to characterize the generality of floodwater resource utilization potential in the basin, the runoff data were analyzed, and the normal year with a $50 \%$ assurance rate was determined as the typical hydrological year, with ten days as the calculation period, and the flood season from the middle of July to the end of September as the calculation period. Taking the discharge data of Hongze Lake and Luoma Lake during the flood season as input, the floodwater resources of the Jiangsu section of the East Route of the SNWT 
project in Jiangsu Province is studied by taking the discharge data of flood dis-charge of Hongze Lake and Luoma Lake as input.

\section{Results and Discussion}

\subsection{Utilization Mode and Potential Evaluation of Flood Resources in the Study Area}

\subsubsection{Estimation of Available Flood Resources}

The Jiangsu section of the East Route of the SNWT project is located in the lower reaches of various major river basins with abundant water resources. Hongze Lake and Luoma Lake have a large amount of abandoned water during flood season every year. If the abandoned water can be optimized and supplied to Beijing, Tianjin, and Hebei region through lake regulation and storage, the benefit of water resources will be maximized.

Hongze Lake is located in the lower reaches of the Huaihe River in the west of the Jiangsu Province, with a total storage capacity of 4.25 billion $\mathrm{m}^{3}$ and a regulation capacity of 3.15 billion $\mathrm{m}^{3}$ during the non-flood season, which is the largest storage area in the system. During the flood season, the water level is $12.5 \mathrm{~m}$, the lake water area is $2069 \mathrm{~km}^{2}$, and the deepest water level is $5.5 \mathrm{~m}$. During the flood season or flood year, the water level can be as high as $15.5 \mathrm{~m}$ and the area can be expanded to $3500 \mathrm{~km}^{2}$. With the completion of the Hongze Lake dike reinforcement project in 2014, the flood control standard of Hongze Lake has reached a 100 year return period. The average annual runoff into the lake of Hongze Lake is 32.51 billion $\mathrm{m}^{3}$ ( $66 \%$ of which is from June to September), and the average annual inflow into the river is 16.48 billion $\mathrm{m}^{3}$, including 11.93 billion $\mathrm{m}^{3}$ during flood season and 5.53 billion $\mathrm{m}^{3}$ in sea, including 1.70 billion $\mathrm{m}^{3}$ in North Jiangsu Irrigation Canal, 2.13 billion $\mathrm{m}^{3}$ in Abandoned Yellow River and 700 million $\mathrm{m}^{3}$ in Huaishuxin River. Hongze Lake completes the water abandonment task by Erhe Sluice and Sanhe Sluice during flood season [27].

Luoma Lake is one of the four largest lakes in Jiangsu Province, which straddles Xuzhou and Suqian. The water area of the lake is $375 \mathrm{~km}^{2}$ (water level is $23 \mathrm{~m}$ ), of which are Suqian City and Xuzhou City with $232 \mathrm{~km}^{2}$ and $143 \mathrm{~km}^{2}$, respectively, and the maximum water capacity is 1.45 billion $\mathrm{m}^{3}$ (water level is $24 \mathrm{~m}$ ). With the completion of the project of flood diversion from east to south of Yishusi River, Luoma Lake has basically reached the flood control standard of a 50 year return period. In flood season, Zhangshan Sluice is mainly used to dispose of the water of Luoma Lake [28]. Refer to the flood control operation dispatching situation map of Hongze Lake and Luoma Lake (Figure 3) for the relevant conditions of Hongze Lake and Luoma Lake [29,30].

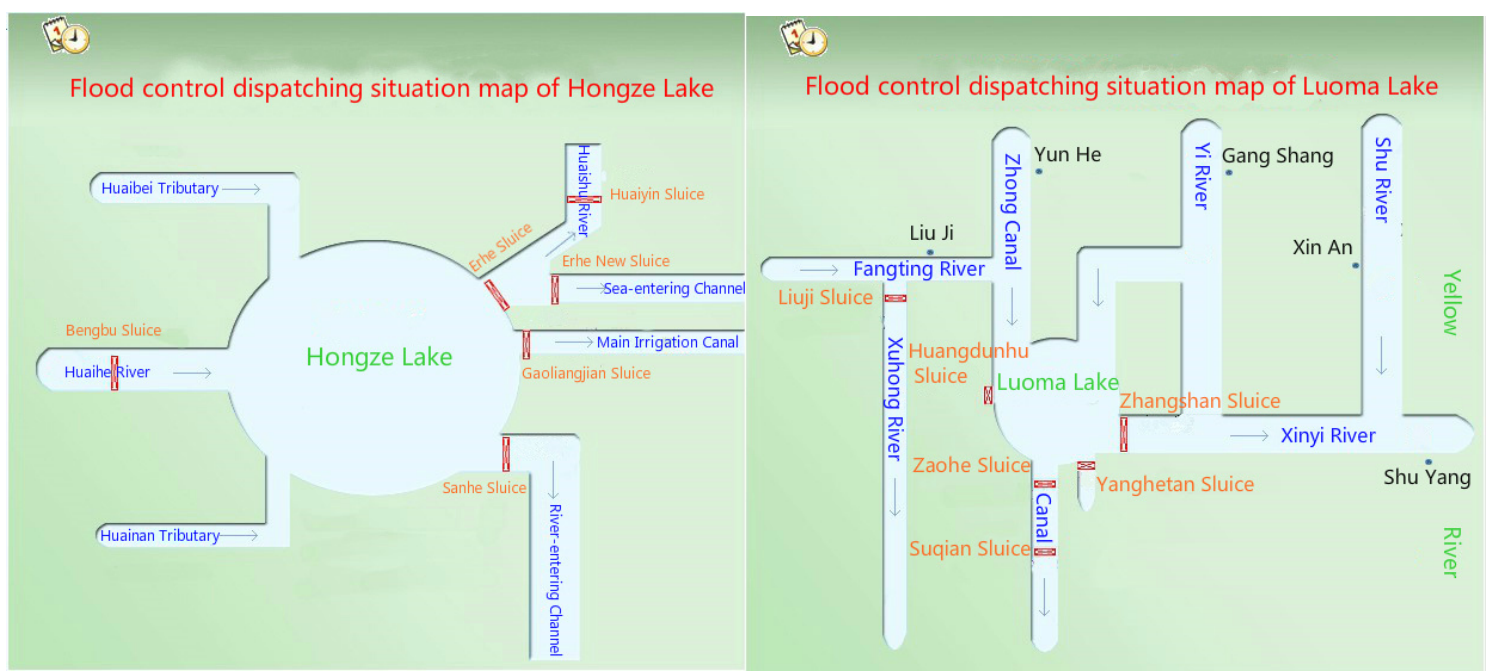

Figure 3. Hongze lake and Luoma lake flood control dispatching situation map. 
According to the situation of the above lakes, this paper collected the daily inflow and outflow data of Hongze Lake and Luoma Lake for the past 15 years from 2003 to 2017: among them, the flood season is from June to September every year. During this period, the amount of water discharged from the Yangtze River is temporarily called abandoned water. The discharge of Sanhe Sluice is considered the abandoned water of Hongze Lake, and Zhangshan Sluice is considered that of Luoma Lake. The annual average floodwater resource of lake group during the flood season is shown in Figure 4.

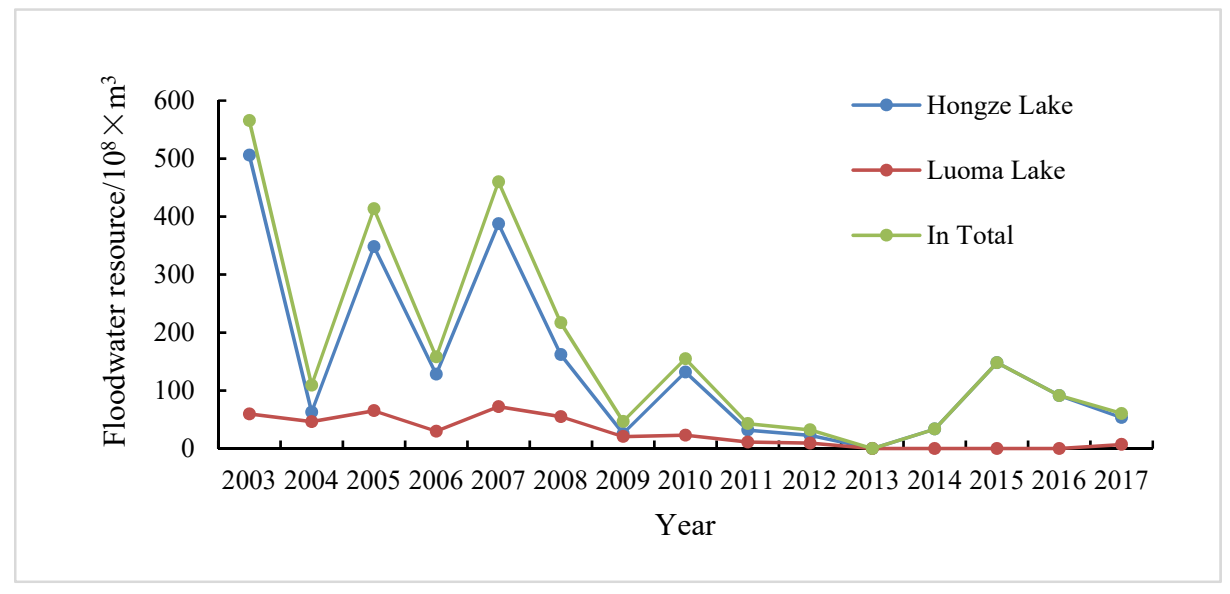

Figure 4. Lake group floodwater resource of July to September of 2003-2007.

The average annual floodwater resource of Hongze Lake and Luoma Lake is 16.885 billion $\mathrm{m}^{3}$; the maximum value is 56.554 billion $\mathrm{m}^{3}$ in 2003, and the minimum value is 0 . Hongze Lake has great flood utilization potential and more floodwater resources. According to the analysis of water use in Jiangsu Province, from June to the first ten days of July is the time of large-scale irrigation water consumption in the province, and this period is the initial stage of flood formation. The water quantity and quality of the lake group is in the process of water storage, so the estimation of the available quantity of floodwater resources of the lake group is set from 15 July to 30 September without affecting the normal operation of the SNWT Project. The estimated results are shown in Figure 5.

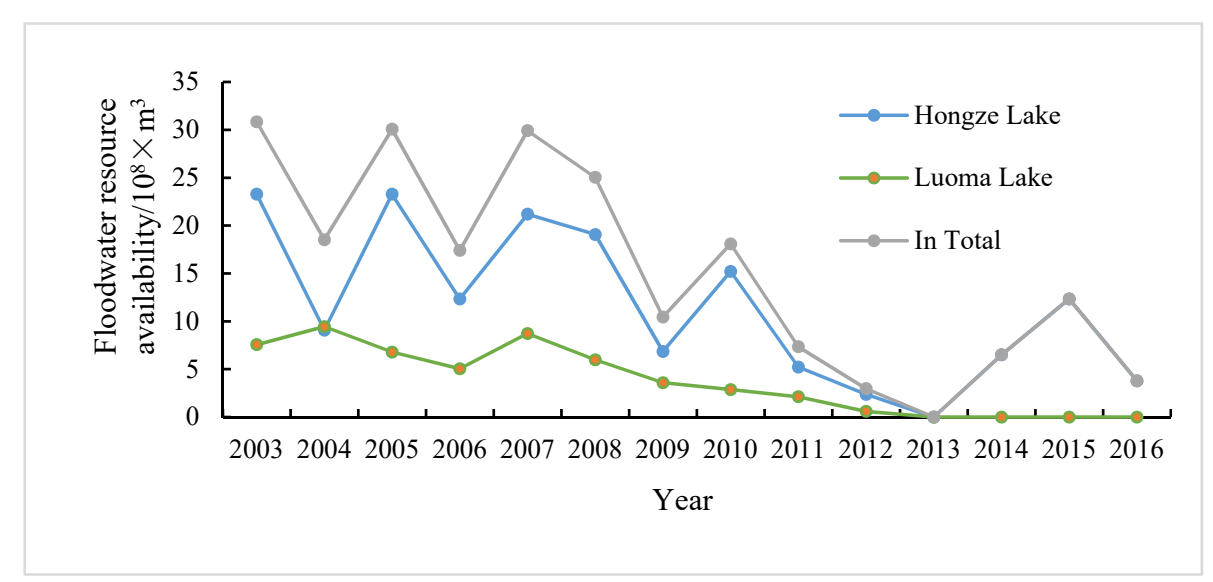

Figure 5. Lake group floodwater resource availability of July to September of 2003-2007.

\subsubsection{Selection of Floodwater Resources Utilization Mode}

According to the existing daily inflow data and water resources bulletin of Hongze Lake and Luoma Lake from 2003 to 2017, the maximum ten day inflow, the maximum 3-day runoff and the maximum 7-day inflow during flood season (15 July-30 September) are calculated. Establishing the multi-dimensional time series matrix, the research period of the flood season is divided into the main flood season (15 July to 15 August) and the later 
flood season (16 August to 10 September, 11 September to 30 September). Among them, the period from 15 July to 15 August is the period of high flood occurrence in the basin with abundant incoming water, which mainly meets the requirements of flood control; in the later flood season, the flood control pressure will be reduced to a certain extent, so it is considered to gradually raise the flood limit water level to ensure that the reservoir can be full at the end of the flood season. In order to reduce the risk of flood control, the rising range of water level in the first half of 16 August to 10 September should be controlled.

It can be seen from the above that the flood control standard of Hongze Lake reaches a 100-year return period and Luoma Lake has a return period of 50 years. The maximum inflow of Hongze Lake and Luoma Lake in different stages from 2003 to 2017 is selected year by year to form the flood peak discharge series. The flood frequency curve by stages is calculated by using the line fitting method, and the design flood peak corresponding to the design standard is obtained. The occurrence of floods is often accidental, and it is not known whether it is advanced or delayed. Therefore, through the "extended period sampling method", the original staging period is extended for 3 days at the same time. The calculation results of design flood by stages of Hongze Lake and Luoma Lake can be seen in Tables 2 and 3. According to the water resources bulletin and other data of the basin, the typical years of preliminary flood resource utilization (the frequency of a high-water year, low-water year and normal-water year are $25 \%, 50 \%$ and $75 \%$ ), and the normal water year is selected as 2010. The design flood process of the Lake during the main flood season and after the flood season is deduced by enlarging the ratio of the design flood peak and design flood peak by stages [31].

Table 2. Hongze Lake design flood calculation by stages results.

\begin{tabular}{|c|c|c|c|c|c|c|c|}
\hline \multirow{2}{*}{ Stages } & \multirow{2}{*}{$\mathrm{Q}_{\mathrm{m}} /\left(\mathrm{m}^{3} / \mathrm{s}\right)$} & \multirow{2}{*}{$\mathrm{Cv}$} & \multirow{2}{*}{$\mathrm{Cs} / \mathrm{Cv}$} & \multicolumn{2}{|c|}{ Peak Discharge $\mathrm{Q}_{\mathrm{p}} /\left(\mathrm{m}^{3} / \mathrm{s}\right)$} & \multicolumn{2}{|c|}{ 3-Day Flood Volume $W_{\mathrm{p}} /\left(10^{8} \times \mathrm{m}^{3}\right)$} \\
\hline & & & & $1 \%$ & $0.05 \%$ & $1 \%$ & $0.05 \%$ \\
\hline Main flood season & 5440 & 0.98 & 2.5 & 7842 & 11,757 & 20.55 & 11.98 \\
\hline $\begin{array}{l}\text { later flood season } \\
\text { (16 August to } \\
10 \text { September) }\end{array}$ & 4133 & 1.96 & 2.5 & 5985 & 7785 & 15.10 & 16.02 \\
\hline $\begin{array}{l}\text { later flood season } \\
\text { (11 September to } \\
30 \text { September) }\end{array}$ & 3874 & 1.03 & 2.0 & 4028 & 6028 & 18.17 & 11.12 \\
\hline
\end{tabular}

Table 3. Luoma Lake design flood calculation by stages results.

\begin{tabular}{|c|c|c|c|c|c|c|c|}
\hline \multirow{2}{*}{ Stages } & \multirow{2}{*}{$\mathrm{Q}_{\mathrm{m}} /\left(\mathrm{m}^{3} / \mathrm{s}\right)$} & \multirow{2}{*}{$\mathrm{Cv}$} & \multirow{2}{*}{$\mathrm{Cs} / \mathrm{Cv}$} & \multicolumn{2}{|c|}{ Peak Discharge $Q_{\mathrm{p}} /\left(\mathrm{m}^{3} / \mathrm{s}\right)$} & \multicolumn{2}{|c|}{ 3-Day Flood Volume $W_{p} /\left(10^{8} \times \mathrm{m}^{3}\right)$} \\
\hline & & & & $1 \%$ & $0.05 \%$ & $1 \%$ & $0.05 \%$ \\
\hline Main flood season & 1479 & 0.95 & 2.5 & 1908 & 2423 & 8.55 & 11.98 \\
\hline $\begin{array}{l}\text { later flood season } \\
\text { (16 August to } \\
10 \text { September) }\end{array}$ & 1785 & 1.12 & 2.0 & 3270 & 4611 & 11.44 & 16.02 \\
\hline $\begin{array}{l}\text { later flood season } \\
\text { (11 September to } \\
30 \text { September) }\end{array}$ & 1919 & 1.08 & 2.0 & 1720 & 2220 & 7.92 & 11.12 \\
\hline
\end{tabular}

Under the safety standard of flood control, according to the design flood by stages and the corresponding discharge mode, the flood regulation calculation is carried out to determine the stage of the flood limit water level. In this paper, under the condition that the design flood level is determined by stages and the design flood level is determined, two methods are adopted to calculate the maximum water level by controlling the discharge flow and to calculate the maximum discharge by controlling the maximum water level [32]. According to the reservoir operation principle, the flood regulation calculation is carried out, and the flood control limit water level is obtained. For the flood control water level of 
Hongze Lake and Luoma Lake, the following schemes are put forward: The flood control pressure in the main flood season is high, and the flood control level of Hongze Lake is $12.5 \mathrm{~m}$ and that of Luoma Lake is $22.50 \mathrm{~m}$, according to the flood regulation scheme of Yishusi river. In the later flood season, the limited water level of Hongze Lake can be raised from $12.5 \mathrm{~m}$ to $13.0 \mathrm{~m}$, and the capacity of the Xingli reservoir will be increased by 696 million $\mathrm{m}^{3}$. The flood limit water level of Luoma Lake can be raised from $22.5 \mathrm{~m}$ to $23.0 \mathrm{~m}$ (16 August to 10 September) and $23.5 \mathrm{~m}$ (from 11 September to 30 September), and the capacity of the Xingli reservoir will be increased by 150-300 million $\mathrm{m}^{3}$.

\subsection{Calculation of Optimal Scheduling Decision Scheme}

After 1000 iterations of the above-mentioned optimal operation model, the non inferior solution front is obtained. The top 10 schemes with the lowest comprehensive risk of flood control are selected, and the optimal operation decision-making scheme in the normalwater year is obtained through a risk-benefit calculation. The water transfer amount of the main pumping lines in this scheme and the corresponding comprehensive risks are shown in Table 4.

Table 4. Water quantity of main pumping lines under different water conditions

\begin{tabular}{|c|c|c|c|c|c|c|}
\hline $\begin{array}{c}\text { Inflow and Outflow of } \\
\text { the Lake }\end{array}$ & July & August & September & Sum & Inflow and Outflow of Canal & $\begin{array}{c}\text { Water Delivery } \\
\text { Capacity }\end{array}$ \\
\hline \multirow{2}{*}{ Outflow Hongze Lake } & \multirow{2}{*}{2.39} & \multirow{2}{*}{2.81} & \multirow{2}{*}{1.33} & \multirow{2}{*}{6.53} & Inflow Zhong Canal & 4.29 \\
\hline & & & & & Inflow Xuhong Canal & 2.24 \\
\hline \multirow{2}{*}{ Inflow Luoma Lake } & \multirow{2}{*}{1.16} & \multirow{2}{*}{1.59} & \multirow{2}{*}{0.10} & \multirow{2}{*}{2.85} & Outflow Xuhong Canal & 0.92 \\
\hline & & & & & Outflow Zhong Canal & 1.93 \\
\hline \multirow{2}{*}{ Outflow Luoma Lake } & \multirow{2}{*}{2.07} & \multirow{2}{*}{1.59} & \multirow{2}{*}{2.07} & \multirow{2}{*}{5.72} & Inflow Bulao Canal & 2.86 \\
\hline & & & & & Inflow Hanzhuang Canal & 2.86 \\
\hline \multirow{2}{*}{ Inflow Nansi Lake } & \multirow{2}{*}{1.54} & \multirow{2}{*}{1.06} & \multirow{2}{*}{1.54} & \multirow{2}{*}{4.13} & Outflow Bulao Canal & 1.55 \\
\hline & & & & & Outflow Hanzhuang Canal & 2.58 \\
\hline $\begin{array}{c}\text { Outflow Nansi Lake } \\
\text { (Jiangsu) }\end{array}$ & 1.54 & 1.06 & 1.54 & 4.13 & Inflow Liangji Canal & 4.13 \\
\hline
\end{tabular}

Under the condition of not violating the regulation principle, the floodwater resources of lakes in the East Route of the SNWT project are optimized. It can be seen from Table 5, considering the flood control risk and the limitation of the project scale, the optimal scheme can transfer out 413 million $\mathrm{m}^{3}$ of floodwater resources of Jiangsu Province during flood season to supply the water shortage areas in the north and reduce the large amount of abandoned water of lakes during flood season; the corresponding comprehensive risk is about 4.29. Due to the utilization of the flood limit water level by stages, the transfer and storage function of the lake after flood season has been increased. It can be seen from the previous study that the reservoir capacity of Hongze Lake is increased by 696 million $\mathrm{m}^{3}$, and Luoma Lake by 150-300 million $\mathrm{m}^{3}$. In addition to the floodwater resource of the Water Transfer Project to North, some floodwater resources can be stored for the nonflood season. If the limited water level during flood season is not used by stages and the optimal operation of the lakes is not carried out, the floodwater resource is utilized directly according to the principle of the South-to-North Water Transfer and Allocation project. The original lake water storage parameters and the scale of the supporting pump station project are strictly controlled. When the inflow water exceeds the flood limit water level of the lake or exceeds the water transfer capacity of the pump station, the water will be discarded according to the original sluice gate. Finally, the maximum amount of water that can be transferred into the Liangii canal in a typical year is 461 million $\mathrm{m}^{3}$. Compared with the results of optimal operation, although the floodwater resources transferred out by the utilization of floodwater resources according to the allocation principle are increased by 48 million $\mathrm{m}^{3}$, this method does not increase the storage capacity of the lake in the flood season and does not consider all kinds of risk factors. The results are relatively one-sided, 
and the floodwater resources are not used to the maximum extent; therefore, the reliability is not high.

Table 5. Comprehensive risk of flood control under the corresponding water transfer scheme.

\begin{tabular}{|c|c|c|c|c|c|}
\hline Risk Category & Risk Indicators & Risk Value & $\begin{array}{l}\text { Combination } \\
\text { Weight }\end{array}$ & $\begin{array}{c}\text { Comprehensive } \\
\text { Risk }\end{array}$ & \\
\hline Risk of water & Hongze LakeC 1 & 7.88 & 0.1258 & 0.991304 & \\
\hline storage project & Luoma LakeC 2 & 4.58 & 0.1049 & 0.480442 & 1.890846 \\
\hline $\mathrm{B}_{1}$ & Nansi Lower LakeC $_{3}$ & 5.08 & 0.0825 & 0.4191 & \\
\hline \multirow{6}{*}{$\begin{array}{c}\text { Risk of water } \\
\text { conveyance project } \\
\mathrm{B}_{2}\end{array}$} & Zhong CanalC 4 & 4.95 & 0.1038 & 0.51381 & \multirow{6}{*}{1.159985} \\
\hline & Xuhong CanalC $_{5}$ & 3.45 & 0.065 & 0.22425 & \\
\hline & Bulao CanalC $_{6}$ & 3.02 & 0.0709 & 0.214118 & \\
\hline & Hanzhuang CanalC ${ }_{7}$ & 3.39 & 0.0613 & 0.207807 & \\
\hline & Siyang StationC 8 & 4.58 & 0.0535 & 0.24503 & \\
\hline & Sihong StationC 9 & 3.72 & 0.042 & 0.15624 & \\
\hline Risk of water lifting & Liulaojian StationC $C_{10}$ & 1.58 & 0.0768 & 0.121344 & \\
\hline project & Suining StationC $C_{11}$ & 1.16 & 0.0296 & 0.034336 & 1.239133 \\
\hline \multirow[t]{3}{*}{$\mathrm{B}_{3}$} & Zaohe Station $C_{12}$ & 4.25 & 0.0626 & 0.26605 & \\
\hline & Pizhou StationC 13 & 2.85 & 0.0533 & 0.151905 & \\
\hline & Liushan StationC 14 & 3.88 & 0.0681 & 0.264228 & \\
\hline Sum & & 54.37 & 1.0001 & 4.289964 & 4.289964 \\
\hline
\end{tabular}

\section{Conclusions}

How to make the best use of the flood season water under the condition of ensuring the safety of flood control is a problem that needs further discussion [33-35]. Based on the existing floodwater resource utilization model system, the abandoned water in the lake group of the East Route of the SNWT Project is utilized, and its utilization potential and the available amount are evaluated. By using the floodwater resource utilization mode of lake flood limited water level by stages, the control water level in the flood season is raised and the storage capacity of the lakes is increased. Then, the optimal operation model of the floodwater resource during the flood season is established with the goal of maximizing the amount of floodwater utilization and minimizing the comprehensive risk value of flood control. The improved particle swarm optimization algorithm is used to solve the problem, and the optimal scheme is determined by a comprehensive benefit calculation. The main conclusions are as follows:

(1) The average annual floodwater resource available in Hongze Lake and the Luoma Lake Basin (2003-2017) has a large amount of utilization. At present, there are some areas along the East Route of the SNWT Project that cannot be covered by the water supply. Although there is water supply in some areas, the water quality cannot meet the standard. The implementation of rainwater and flood resource utilization can alleviate the problem of water use in blind spots of water supply to a certain extent. Future development is needed to improve their own water supply capacity and improve the water supply guarantee rate; the development and utilization of rainwater resources is necessary.

(2) According to the different periods of the flood season, the flood limit water levels of Hongze Lake and Luoma Lake have been increased correspondingly. After the completion of the first phase of the east line project, the water supply did not reach the design capacity of 1.353 billion $\mathrm{m}^{3}$, which was planned for the first phase of the project. Before the implementation of the second phase of the project, the joint dispatching management measures and a small number of new engineering measures should be taken to make full use of the water supply capacity of the first phase of the project and the water supply potential in the whole year, and extend the emergency water supply to Beijing, Tianjin and Hebei, three provinces (municipalities directly under the central government) to the north, to realize the rational utilization of water resources, which can maximize the regulation and storage capacity of the lakes and give full play to the benefits of the first phase of the project. 
(3) According to the optimal operation scheme, the comprehensive risk value of flood control is relatively low. According to the principle of moderate risk and ensuring the operation of the risk management mechanism in the east line of the SNWT Project, the comprehensive utilization risk is within the acceptable range. On the premise of stable meeting safety, we can coordinate various relations and make full use of water resources in order to better achieve the established water supply target.

The optimal operation of flood resources of lakes in the East Route of the SNWT Project can make full use of the water supply capacity of phase I of the project, make full use of the flood benefits, and realize the rational utilization of water resources. It is of great significance to alleviate the contradiction between water resources shortage and flood control, improve the ecological environment along the line and realize the sustainable utilization of water resources. However, the elevation of lake water level will have a certain impact on the surrounding environment and flood control safety, so corresponding impact treatment projects should be provided, such as the lakeside dike protection project, and lake river channel impact treatment project, and corresponding compensation should be made. The lake group system of the East Route of the SNWT Project is complex and the hydrological conditions are changeable. It is not mature nor comprehensive to apply the flood resource utilization model to the East Route of the SNWT Project. Further research and application should be strengthened.

Author Contributions: Conceptualization, Z.Y. and X.H.; methodology, Z.Y. and X.H.; software, Z.Y.; validation, X.H.; formal analysis, Z.Y.; investigation, J.L.; resources, J.L.; data curation, J.L.; writingoriginal draft preparation, Z.Y. and J.L.; writing—review and editing, Z.Y. and X.H.; visualization, Z.Y.; supervision, G.F.; project administration, G.F.; funding acquisition, X.H. All authors have read and agreed to the published version of the manuscript.

Funding: This research was funded by National Key Research and Development Program of China (2018YFE0128500); Science and technology project of Huaneng Group Headquarters "Research on Key Technologies of Water Light Complementary Construction of 10 MW Clean Energy Base in Lancang River Tibet section" (HNKJ20-H20); and Water Conservancy Science and Technology Program of Jiangsu (2019016).

Institutional Review Board Statement: Not applicable.

Informed Consent Statement: Not applicable.

Data Availability Statement: Not applicable.

Conflicts of Interest: The authors declare no conflict of interest.

\section{References}

1. Katyal, A.; Petrisor, I. Flood Management Strategies for a Holistic Sustainable Development. Environ. Forensics 2011, 12, $206-218$. [CrossRef]

2. Deng, P.; Xu, G.; Bing, J.; Xu, C.; Jia, J. Evaluation method of rain-flood resource utilization availability and its application in the Hanjiang River Basin. J. Water Sci. Technol. Water Supply 2020, 20, 3557-3575. [CrossRef]

3. Liu, Y.; Qin, H.; Mo, L.; Wang, Y.; Chen, D.; Pang, S.; Yin, X. Hierarchical Flood Operation Rules Optimization Using MultiObjective Cultured Evolutionary Algorithm Based on Decomposition. J. Water Resour. Manag. 2019, 33, 337-354. [CrossRef]

4. Takeuchi, K. Flood management in Japan-From rivers to basins. J. Water Int. 2002, 27, 20-26. [CrossRef]

5. Kumar, D.N.; Baliarsingh, R.; Raju, R.S. Optimal Reservoir Operation for Flood Control Using Folded Dynamic Programming. J. Water Resour. Manag. 2010, 24, 1045-1064. [CrossRef]

6. Shen, D.; Speed, R. Water resources allocation in the People's Republic of China. Int. J. Water Resour. Dev. 2009, 25, 209-225. [CrossRef]

7. Pal, S.K.; Adeloye, A.J.; Babel, M.S.; Gupta, A.D. Evaluation of the effectiveness of water management policies in Bangladesh Water Resour. Dev. 2011, 27, 401-417. [CrossRef]

8. Zhai, G.; Ikeda, S. Empirical analysis of Japanese flood risk acceptability within multi-risk context. Nat. Hazards Earth Syst. Sci. 2008, 8, 1049-1066. [CrossRef]

9. Maqsood, I.; Huang, G.H. A dual two-stage stochastic model for flood management with inexact-integer analysis under multiple uncertainties. J. Stoch. Environ. Res. Risk Assess. 2013, 27, 643-657. [CrossRef]

10. Sheehan, J.; Brown, J. Flood risk management: Property rights-focussed instruments in Australia. J. Environ. Sci. Policy 2021, 119, 12-17. [CrossRef] 
11. Mobley, W.; Sebastian, A.; Blessing, R.; Highfield, W.E.; Stearns, L.; Brody, S.D. Quantification of continuous flood hazard using random forest classification and flood insurance claims at large spatial scales: A pilot study in southeast Texas. J. Nat. Hazards Earth Syst. Sci. 2021, 21, 807-822. [CrossRef]

12. Hua, L.; Wan, X.; Wang, X.; Zhao, F.; Zhong, P.; Liu, M.; Yang, Q. Floodwater Utilization Based on Reservoir Pre-Release Strategy Considering the Worst-Case Scenario. J. Water 2020, 12, 892. [CrossRef]

13. Qiu, Y.; Liu, Y.; Liu, Y.; Chen, Y.Z.; Li, Y. An interval two-stage stochastic programming model for floodresources allocation under ecological benefits as a constraint combined with ecological compensation concept. Int. J. Environ. Res. Public Health 2019, 16, 1033. [CrossRef]

14. Dadmand, F.; Naji-Azimi, Z.; Farimani, N.M.; Davary, K. Sustainable allocation of water resources in water-scarcity conditions using robust fuzzy stochastic programming. J. Clean. Prod. 2020, 276, 123812. [CrossRef]

15. Water Resources Department of Jiangsu Province. Study on the Utilization of Flood Resources in the First Phase of the East Line of South to North Water Transfer Project; Hohai University: Nanjing, China, 2017.

16. Wang, W.J.; Wu, X.W.; Fang, G.H.; Wen, X. Optimal water operation in Jiangsu section of the South-to-North Water Diversion Project. J. South-to-North Water Transf. Water Sci. Technol. 2015, 13, 422-426. (In Chinese)

17. Fang, G.H.; Zhu, X.H.; Huang, X.F. Risk analysis of floodwater resources utilization along water diversion project: A case study of the Eastern Route of the South-to-North Water Diversion Project in China. J. Water Sci. Technol. Water Supply 2019, 19, 2464-2475. [CrossRef]

18. Feng, X.; Qiu, B.; Cao, H.; Wei, Q.; Teng, H. Optimal Operation for Baoying Pumping Station in East Route Project of South-toNorth Water Transfer. Chin. J. Mech. Eng. 2009, 1, 78. [CrossRef]

19. Li, X.Y.; Li, F.F.; Qiu, J. A New Evaluation for Water Transfer Optimal Schemes with the Consideration of Reliability, Stability, and Severity. J. Water Resour. Manag. 2017, 31, 2823-2836. [CrossRef]

20. Ouyang, S.; Zhou, J.; Li, C.; Liao, X.; Wang, H. Optimal design for flood limit water level of cascade reservoirs. Water Resour. Manag. 2015, 29, 445-457. [CrossRef]

21. Chen, Q.; Li, J.; Li, R.; Wei, W.; Wang, L. River basin water resource compensation characteristics by set pair analysis: The Dongjiang example. Front. Earth Sci. 2014, 8, 64-69. [CrossRef]

22. Chang, J.; Guo, A.; Du, H.; Wang, Y. Floodwater utilization for cascade reservoirs based on dynamic control of seasonal flood control limit levels. Environ. Earth Sci. 2017, 76, 1-12. [CrossRef]

23. Zhou, Y.; Guo, S.; Liu, P.; Xu, C. Joint operation and dynamic control of flood limiting water levels for mixed cascade reservoir systems. J. Hydrol. 2014, 519, 248-257. [CrossRef]

24. Huang, X.F.; Lin, J.; Qu, X.P.; Fang, G.; Zhu, L. Research on Water Level Control Scheme of Reservoir Flood Resources Utilization Considering Dam Safety and Risk Benefit. In ACSR-Advances in Computer Science Research, Proceedings of the 3rd International Conference on Mechatronics, Robotics and Automation (ICMRA 2015), Shenzhen, China, 20-21 April 2015; Atlantis Press: Shenzhen, China, 2015; pp. 67-72.

25. Ostadrahimi, L.; Marino, M.A.; Afshar, A. Multi-reservoir Operation Rules: Multi-swarm PSO-based Optimization Approach. J. Water Resour. Manag. 2012, 26, 407-427. [CrossRef]

26. Hou, Y.; Guo, S.; Xu, C.-Y.; Liu, D.; Chen, L.; Wang, D. Integrated optimal allocation model for complex adaptive system of water resources management (II): Case study. J. Hydrol. 2015, 531, 977-991.

27. Zeng, C. Research of water resources allocation of South-to-North Water Diversion East Route Project in Jiangsu Province, Eastern China. Agu Fall Meeting. In AGU Fall Meeting Abstracts (2015); AGU Publication: Nanjing, China, 2015.

28. Duan, G.M.; Zhao, J.Z.; Liu, G.H. Eco-environmental benefit assessment of China's South-North Water Transfer Scheme-The middle route project. J. Environ. Sci. 2004, 16, 308.

29. Yuan, X.; Wang, H.; Li, Q.; Feng, Y. Analysis on interconnection between water resources of Hongze Lake and Luoma Lake and study on coupled model for its optimal regulation. J. Water Resour. Hydropower Eng. 2016, 47, 9-14.

30. Hu, B.; Wang, P.F.; Qian, J.; Wang, C.; Zhang, N.N.; Cui, X.A. Characteristics, sources, and photobleaching of chromophoric dissolved organic matter (CDOM) in large and shallow Hongze Lake, China. J. Great Lakes Res. 2017, 43, 1165-1172. [CrossRef]

31. Jiang, Z.; Sun, P.; Ji, C.; Zhou, J. Credibility theory based dynamic control bound optimization for reservoir flood limited water level. J. Hydrol. 2015, 529, 928-939. [CrossRef]

32. Huang, X.F.; Chen, Y.Q.; Lin, J.; Fang, G.; Qu, X.; Zhu, L. Research on benefit of reservoir flood resources utilization based on the dynamic control of limited water level. J. Desalination Water Treat. 2017, 79, 214-220. [CrossRef]

33. Jiang, H.; Yu, Z.; Mo, C. Reservoir Flood Season Segmentation and Optimal Operation of Flood-Limiting Water Levels. J. Hydrol. Eng. 2014, 20, 05014035. [CrossRef]

34. Yao, H.Y.; Dong, Z.C.; Jia, W.H.; Ni, X.; Chen, M.; Zhu, C.; Li, D. Competitive Relationship between Flood Control and Power Generation with Flood Season Division: A Case Study in Downstream Jinsha River Cascade Reservoirs. Water 2019, 11, 2401.

35. Zhou, H.C.; Wang, F.X.; Liang, G.H. Decision-making on reservoir flood control level and its control manner in post-flooding seasons for Biliuhe Reservoir. J. Adv. Water Sci. 2009, 20, 857-862. 